Carlos A. Pereira

carlos.pereira@campus.ul.pt

\title{
Wittgenstein on Vaihinger and Frazer
}

\section{Abstract}

In this paper I demonstrate the connection between the single remark Wittgenstein made explicitly on Hans Vaihinger's Die Philosophie des als $o b$ and the remarks he made on Sir James George Frazer's The Golden Bough. After a critical-genetic exposition of the relevant material, I offer an interpretation of that connection, which will require that I interpret the remark on the philosophy of "as if" relative to how Wittgenstein seems to regard Vaihinger's fictionalism and relative to how Wittgenstein reads Frazer.

\section{Critical-genetic notes}

Scholars have noticed (cf. Rothhaupt 1995 and Biesenbach 2011: 380) that the Nachlass contains a single remark made in passing on Hans Vaihinger's Die Philosophie des als ob, but this remark has yet to be adequately contextualized and interpreted. In published form, it appears only in editions of Zettel, following TS 233a: 54 (= Z \$261), which reads:

Die "Philosophie des Als Ob" beruht selbst // ganz // auf dieser Verwechslung zwischen Gleichnis und Wirklichkeit.

TS 233a: 54 shows that the remark is typed along with two others on one out of a number of fragments attached to the page. This suggests that these three remarks came together from some other, 
previous item. The fragment is TS 211: 281, which, according to von Wright (1982: 47), dates from 1932 and reads as follows:

Man kann in der Logik die Allgemeinheit nicht weiter ausdehnen, als unsere logische Voraussicht reicht. Oder richtiger: als unser logischer Blick reicht.

Man kann nur scheinbar "über jede mögliche Erfahrung hinausgehen"; ja, dieses Wort hat auch nur scheinbar Sinn, weil es nach Analogie sinnvoller [a $\mid$ A] usdrücke gebildet ist.

Die "Philosophie des Als Ob" beruht selbst // ganz // auf dieser Verwechslung zwischen Gleichnis und Wirklichkeit.

A comparison between both items (TS 233a: 54 and TS 211: 281) shows how the context of the remarks quoted above differs in terms of their neighbouring text, notably the immediately following remark in TS 211: 281, which reads:

In den alten Riten haben wir den Gebrauch einer äusserst ausgebildeten Gebärdensprache.

Und wenn ich in Frazer lese, so möchte ich auf Schritt und Tritt sagen: Alle diese Prozesse, diese Wandlungen der Bedeutung, haben wir noch in unserer Wortsprache vor uns. Wenn das, was sich in der letzten Garbe verbirgt, der 'Kornwolf' genannt wird, aber auch diese Garbe selbst, und auch der Mann der sie bindet, so erkennen wir hierin einen uns wohlbekannten sprachlichen Vorgang.

This suggests that Wittgenstein's remark on Vaihinger was initially thought of with Frazer in mind. In effect, the remark was originally handwritten in the summer of 1931 after Wittgenstein began reading Frazer's The Golden Bough, which he did with Maurice O'Connor Drury earlier that year (Cf. Drury 1984: 119). For the sake of precision I should mention that, in his editions of the remarks on The Golden Bough, Rush Rhees quotes Drury as saying that they had read Frazer in 1930, while in his own "Conversations with Wittgenstein" Drury places their reading of Frazer in 1931, as Klagge and Nordmann point out (PO: 115). I side with Drury's own unquoted voice, fully aware that personal recollections can be unreliable. Everybody agrees, however, on the date at which Wittgenstein began writing about The Golden Bough: the summer of 1931. 
This is what the first instance (MS 110: 255-256) of the remark looks like, according to the normalized transcription in BEE, within its immediately preceding and following text:

Man kann nur scheinbar „über jede mögliche Erfahrung hinausgehen"; ja, dieses Wort hat auch nur scheinbar Sinn, weil es nach Analogie sinnvoller Ausdrücke gebildet ist.

„Vielseitige Betrachtung der Zahlen”.

Wenn es einem Menschen freigestellt wäre sich in einen Baum eines Waldes gebären zu lassen: so gäbe es Solche, die sich den schönsten oder höchsten Baum aussuchen würden, solche die sich den kleinsten wählten und solche die sich einen Durchschnitts- oder minderen Durchschnittsbaum wählen würden, und zwar meine ich nicht aus Philiströsität, sondern aus eben dem Grund, oder der Art von Grund, warum sich der Andre den höchsten gewählt hat. Daß das Gefühl welches wir für unser Leben haben mit dem eines solchen Wesens, das sich seinen Standpunkt in der Welt wählen konnte, vergleichbar ist, liegt, glaube ich, dem Mythus - oder dem Glauben - zugrunde, wir hätten uns unsern Körper vor der Geburt gewählt.

Die „Philosophie des Als Ob” beruht ganz auf diese Verwechslung zwischen Gleichnis und Wirklichkeit.

Die Erfüllung des Satzes ,p ist der Fall' ist: daß p der Fall ist. Und weiter nichts.

In den alten Riten haben wir den Gebrauch einer äußerst ausgebildeten Gebärdensprache.

Und wenn ich in Frazer lese so möchte ich auf Schritt \& Tritt sagen: Alle diese Prozesse diese Wandlungen der Bedeutung haben wir noch in unserer Wortsprache vor uns. Wenn das was sich in der letzten Garbe verbirgt der Kornwolf genannt wird, aber auch diese Garbe selbst, und auch der Mann der sie bindet, so erkennen wir hierin einen uns wohlbekannten sprachlichen Vorgang.

The passage above begins with what is now known as $Z$ \260, followed by a sentence marked " $\mathrm{S}$ " (schlecht) for elimination. Then comes a remark on Frazer (GB 1993: 137), after which follows the remark on Vaihinger (again, only published as Z \$261), and then a remark which Wittgenstein was not sure he would use (it has a question mark on its left margin). Finally, there are some more 
remarks on Frazer (GB 1993: 135). (I refer to GB 1993, included in $\mathrm{PO}$, since it is arguably the most comprehensive edition.)

In sum, the complete presence of the remark on Vaihinger in the Nachlass is MS 110: 255-256 $\rightarrow$ TS 211: $281 \rightarrow$ TS 233a: $54(=$ $\mathrm{Z}$ \$261), and we know from this that it was originally thought of in connection with Frazer. We know this not because of MS 110: 255256 alone, which Wittgenstein could have written the remark as an unconnected thought, without being necessarily thinking of The Golden Bough), but because TS 211: 281 confirms the connection; for he could have had the text typed otherwise and deliberately did not. The fact that the remark on Vaihinger originally handwritten in 1931 was typed along with remarks on Frazer in 1932 shows that it was not originally an isolated thought, but a thought stemming from and included in his reading of Frazer.

There is a second set of remarks on Frazer, MS 143, twenty-one pages long (von Wright 1982: 45) and written several years later; according to Rush Rhees, "not earlier than 1936 and probably after 1948" (GB 1967: 234). Since Rhees' inaugural publication of both sets of remarks in the journal Synthese under the title "Bemerkungen über Frazers Golden Bough", a host of different editions with varying selections of Wittgenstein's remarks on Frazer (translated, in German, or bilingual) have been published. However, none of them, to my knowledge, has ever included the remark on Vaihinger. Whether or not this is a sign of questionable editorial decisions is not my present concern, although I suspect that what Andrzej Orzechowski and Alois Pichler (1995) wrote years ago about the then available editions of the remarks on Frazer is still valid today:

[...] the public still hasn't been provided with an edition which can truly be said to form a reliable basis for accurate research and translation. Not only do they contain errors, some of the editions are also - without notifying the reader - abridged.

The remark on Vaihinger may or may not be yet another case of abridgement, and I am not making the point that it ought to be included, nor am I claiming that it is of crucial importance for an understanding of Wittgenstein's remarks on The Golden Bough. What I am pointing out is that, because it was only published in Zettel, 
there has been no apt interpretation of the seemingly obscure reference to Die Philosophie des als ob, for it was apropos the reading of Frazer that Wittgenstein thought of Vaihinger's book - an influential book at the time (Mead 1913: 248-275) and today in philosophy (Fine 1993) as well as in other domains of discourse (e.g. Stampfl 1998).

I will not engage here in an extended discussion of Wittgenstein's remarks on Frazer such as the ones held by Clack (1998) or Cioffi (1998), not only in order to keep the present article to the point, but also because I agree with P. M. S. Hacker when he says that "If one wants to learn from them [the remarks on Frazer], they should not be squeezed too hard" (2001: 75). That is to say: I am not interested in discussing whether or not Wittgenstein had e.g. a theory of religion, or of ritual, as the expression of spiritual or psychological needs and impulses. My ultimate aim is merely to comment on the remark Wittgenstein made explicitly on Vaihinger in connection with Frazer. Having situated the remark within the Nachlass, I will look at each context in detail. First, however, I must introduce the philosophy of "as if".

\section{Vaihinger's fictionalism}

Apart from the remark on which the current paper focuses, there is to my knowledge no other evidence that Wittgenstein had read Vaihinger's Die Philosophie des als ob. However, even if the remark did not exist in the Nachlass it would still be plausible to assume that Wittgenstein was aware of the book since it became very wellknown throughout Europe in the 1920s and 30s, for better and for worse: the Vienna Circle despised it (Fine 1993: 3), while people like Sigmund Freud and Alfred Adler saw their own work positively influenced by it (Szasz 1974: 234). In 1924 C. K. Ogden translated an abridged version into English (still around 400 pages long) entitled The Philosophy of 'As If': A System of the Theoretical, Practical and Religious Fictions of Mankind. The original (1911) German title (Die Philosophie des als ob: System der theoretischen, praktischen und religiösen Fiktionen der Menschheit auf Grund eines idealistischen Positivismus, mit einem Anhang über Kant und Nietzsche) had an additional reference to Kant and Nietzsche since Vaihinger believed that his work 
followed, and made developments on, Kantian and Nietzschean tenets.

For my present purposes I first need to introduce and comment on the general outline of the position Vaihinger claims to hold, which he calls "Critical Positivism". According to this,

there is no Absolute, no Thing-in-itself, no Subject, no Object. All that remains is sensations, which exist, and are given, and out of which the whole subjective world is constructed [...]. Critical Positivism asserts that any further claim is fictional, subjective and unsubstantiated. [...] Any explanation going beyond this can only do so by using the accessories of discursive thought, i.e. through fictions. The only fictionless doctrine in the world is that of Critical Positivism. (Vaihinger 1935: 77)

The obvious difficulty made explicit in the last sentence is closely related to the radical relativistic and sceptical arguments according to which all theorizing is subject to doubt except, inexplicably, those relativistic and sceptical theories themselves. Just as we could ask the radical sceptic if he is sure of his scepticism and the radical relativist whether or not his assertions are relative as well, we could at this point ask Vaihinger how the claim that all discursive thought goes beyond the sensations and thus is a fiction is not itself eo ipso fictional. Another major difficulty is that Vaihinger proposes different theories at different moments of his book.

Throughout the bulk of his book, Vaihinger in effect defends the view that, in all domains of discourse, we make-believe some (not all) false propositions as if they were true in virtue of their usefulness. Such useful false propositions are what he calls "fictions". This time, instead of saying that all discourse is fictional (except that very proclamation), Vaihinger recognizes that there are, in fact, many true propositions. Having established this point, he goes on to distinguish between useless and useful false propositions, as an attempt to defend the idea that falsehood can very often be methodologically (scientifically) desirable. Evidently, this is yet another difficult claim to make not only because it entails that getting things wrong is a useful method of getting things right (and this is very different from the trial and error method, in which the error is abandoned once detected), but also because we must 
suppose that e.g. propositions as varied as "God is the father of men" (Vaihinger 1935: 28), "human actions are free" (43), or "this is a perfect circle" (52), are all not believed to be actually true but taken tongue-in-cheek as if true. In fact, for Vaihinger "all the nobler aspects of our life are based upon fictions" (84); yet, only as long as they serve a purpose:

As long as such fictions are treated as hypotheses without a realization of their nature, they are false bypotheses. They derive real value only if it is realized that they have been deliberately constructed as provisional representations which at some future time are to make room for better and more natural systems. (19)

Here speaking about his prime concern - the status and method of science - Vaihinger claims that, e.g., artificial (false) scientific classificatory systems should not be immediately discarded "in so far as they perform a beuristic service by preparing for and facilitating the discovery of a natural system" (18), which implies the idea that a natural system "must be a copy corresponding to the actual origins and the mutual relationships of all things" (17). Clearly affirming the possibility of language being true of the world (or better yet: that it can be a copy of the world), this passage is, as we saw above, something that he also denies. But let us disregard the self-refuting claim that all theorizing is a fiction except the fictionalist doctrine itself and stay with this new idea that there is at least the possibility of a scientific system such that it is a picture of the world and that sometimes (or very often) false propositions or systems may aid us in getting there.

Now, while Vaihinger's idea of fiction, under the present terms, is entirely dependent on the conception of language as corresponding to the world, the fact that he claims that fictions are of practical use makes him a pragmatist of sorts, for he is saying that what matters most is not so much truth but, ultimately, whatever is working, although his is "a view of pragmatism differing from that of James and Peirce" and "closer to capturing Poincaré's philosophy" (Bouriau 2009: 223) - which is just another way of saying that his notion of usefulness is always considered in relation to falsehood. Ironically, this in turn ties him to a strong notion of Truth, while American pragmatism tends to equate 
usefulness with truth, at least in Vaihinger's understanding of it (Vaihinger 1935: viii).

Vaihinger hesitates: he is never really sure whether he is a radical sceptic, some kind of pragmatist, or a radical positivist, although his emphasis on practical purposes and his pervading suggestion that most discourse is knowingly false manifests his tendency to imagine, for one, that our beliefs could be submitted to our will, and this is what authorizes him to say that we deliberately operate under make-believe in order to cope with the world and, hopefully, arrive at the truth about it - although this last claim, as we have been seeing, is something he affirms as much as denies. Vaihinger's "as if' means that, on the one hand, beliefs may be knowingly made up, which not only threatens the very idea of truth but also suggests the logically conflicting idea that we do not really believe in what we believe.

On the other hand, he simply assumes that a certain set of descriptions are true pictures of the world without having a theory for such an assumption other than taking for granted his contemporary scientific beliefs. Consequently, Vaihinger's combination of (or alternation between) elements from positivism and from pragmatism managed the feat of stirring up the imagination of many different people with different interests. Nevertheless, it was hard for him to be entirely welcomed by either positivists or pragmatists, for the former saw that his "as if" undermined the rigorous picturing of the world they were attempting to substantiate and the latter would never accept his conception (a Platonist version) of "the actual" truth, which is a logical requisite for a fiction, in his terms, to count as such in the first place. Trapped between the claim that we can get at Truth and the idea that science uses fictions (and not considering his sweeping sceptical proclamations), Vaihinger's view would require a robust argument (which he does not have) explaining how we can make the simple distinction between true and false propositions (useful or not), other than his repeated appeal to the reader according to which it is "obvious" that such-and-such is a fiction or that so-andso is not (Vaihinger 1935: 61, 110, 117, 144, 176, 240). 


\section{The remark on Vaihinger in Zettel}

We can now return to Wittgenstein and to the contexts where his remark on Vaihinger is located. We begin in reverse chronological order by looking at the most recent instance of the remark, TS 233a: 54. Except for (i) the single remark in TS 233a: 54a (inserted by Anscombe and von Wright as Z \$259), (ii) the exclusion from Zettel of an incomplete remark in TS 233a: 55 (previously published in complete form in PI, I, \$385), and (iii) negligible changes in a few remarks such as $Z \$ 265$, the set of remarks I will refer to is exactly the same both in terms of sequence and in terms of content in TS 233a and Zettel. In what follows I will refer only to Zettel which has normalized text and numbered remarks.

The remark is placed within a discussion that revolves around mistaken ways of thinking about experience and thought, which, in fact, amounts to an elucidation of some aspects of language. Wittgenstein connects some remarks on geometry, mathematics and colour (he persistently does so throughout the years: e.g. RPP I \$624; RPP II $\int \S 421,423,425-426$; ROC I $\$ 66$; ROC III $\left.\int \S 3,86\right)$ in order to say, most relevantly for the present purposes, that the intelligibility of experience is circumscribed within "our logical vision" (my quotes will follow Anscombe's translation), which in other places he notoriously calls our grammar (e.g. PR \$1). This is extremely important. The intelligibility of what we experience is delimited by our conceptual framework, which means that, in a certain sense, experience is thought: Just like we cannot know what is it like to be a bat, or think of a new integer between, say, one and two, we cannot think of an undiscovered colour; not because we have never seen or experienced it, but rather because our concepts of colour are already complete (Z \$257).

Evidently, we talk about colour mostly in empirically verifiable contexts. Wittgenstein, however, is here only speaking of the conceptual intelligibility of the experience of colour. (It is beyond the scope of my paper to evaluate all of Wittgenstein's writings on problems such that of "reddish green", cf. Andrew Lugg (2010).) ${ }^{1}$

\footnotetext{
${ }^{1}$ In Lugg's argument, Wittgenstein over the years "goes back and forth - some would say he vacillates" (2010: 172) between the idea that the conceptual octahedron of colours is
} 
On the one hand, we cannot experience something we cannot logically think of, which is another way of saying that, in thought, we cannot "transcend any possible experience" ( $Z$ \$260). On the other hand, reality is not a mere projection of thought, as if it could be a figment of the imagination. This is a point that Wittgenstein makes by saying that thought cannot be used as "an extension of experience", for we "can transmit talk, but not measles, by telephone" ( $\mathrm{Z}$ \256). That is: even though it is logically possible to imagine the case in which measles are in fact transmitted by telephone, just as much as we can "imagine a human society in which it counts as dishonest to calculate, except as a pastime" ( $\mathrm{Z}$ \$252), and while we may hold the false belief that it can be so, we cannot merely think in order to find out empirical states of affairs, much less transmit measles by sheer force of thought. Therefore, the idea that, in thought, we can "transcend any possible experience" ( $Z$ \260) is senseless for several reasons: not only can we not think the logically unthinkable, we cannot think what could never be experienced either, and we cannot just fancy the world to be as we will, as if the world (and our beliefs) could be changed by mental fiat. The picture of the imagination as a boundless space of creative activity is wrong, then, at least in two respects, for the logical bounds of concepts and the brute existence of reality are the necessary intelligible ground we stand on in order to make sense of what we think and say.

However, we can say the unimaginable, even though such utterances only appear to make sense. Hence Wittgenstein states, "there is something right about saying that unimaginability is a criterion for nonsensicality" ( $Z$ \$263). Linguistic illusions of this kind (e.g. the idea of going beyond any possible experience) are as it were "sayable" only because our uses of language can be formed multifariously in analogy with other sound uses ( $\mathrm{Z}$ \260). This last

colour and the suspicion that it might be possible to perceive colours beyond it. To repeat, and even though I agree with Lugg at least in that Wittgenstein does not seem to have a theory (in the old-fashioned, treatise-like sense), I am only interested at present in a close reading of Zettel, more specifically of the immediate context of the remark on Vaihinger, which needs to be unpacked. In this context, Wittgenstein is unequivocally addressing the non-empirical aspect of the intelligibility of colour.) 
point about analogical verbal formation is very important, since it is part of Wittgenstein's early thoughts towards the more malleable (if compared to the idea of calculation) idea of language-games. Most importantly for my purposes, analogical formation appears in the remarks on Frazer's The Golden Bough.

It should be clear that Wittgenstein is not deeming the formation of descriptions on the analogy of other descriptions to be inherently or necessarily senseless. He is not wedded to a conception of language as picture of the world such that he would be saying that there are picturing (meaningful) statements, on one side, and non-picturing (senseless) statements formed by analogy, on the other. His remarks on the misapplication of words do not follow from that kind of picture theory of language. The philosophical mistake he is pointing out, then, is a matter of treating a verbal construction as meaningful just because it could be said; for it does not follow from the fact that a particular sentence can be said that it makes sense, much less that it is true.

Now, Wittgenstein states that the core of Vaihinger's book is a particular confusion:

Die "Philosophie des Als Ob" beruht ganz auf dieser Verwechslung zwischen Gleichnis und Wirklichkeit. (Z \$261)

Anscombe translated "Verwechslung" as "shifting", but Wittgenstein's negative undertones might be missed in Anscombe's wording; the idea is that of "mistaking one thing for the other", which in this case means, I believe, to confuse a simile ("Gleichnis") with reality ("Wirklichkeit"). In the context of the neighbouring remarks, Wittgenstein is connecting Vaihinger's book with the fantasy that we can transcend any possible experience; but, while it is clear how Vaihinger's description of his "Critical Positivism" (according to which beliefs are not really believed in) qualifies as a case of that idea, it is less obvious how it applies to his less radical theory of fictions, as discussed in section 2, and what it has to do with the confusion at stake in Wittgenstein's remark.

In its moderate version (i.e. not counting the general scepticism about thought), Vaihinger's theory of fictions logically requires the conception of language as picture of the world, since without this 
conception his notion of "fiction" would have no application. In fact, prior to his so-called discovery of the heuristic usefulness of certain false propositions, he can only claim to have detected them in all domains of discourse (and can only claim they may be useful) by having assumed that other propositions are True, in the strong sense of true according to which they are given and fixed. As we have seen, he has no thesis to support this latter assumption and he is even silent about the criteria under which he distinguishes true propositions from false ones. Instead, Vaihinger attempts to formulate what seems to be a scientific method that consists, in short, in the attempt to "use thought to make an extension of experience" ( $Z$ \$256) and thereby to transcend experience in thought. In effect, Vaihinger's fictions consist in the idea of taking as if true what empirical experience is believed to deny (e.g. to take as if true that measles are transmitted by telephone) in order to then use such fictions theoretically to talk about the world. In other words, it is to entertain thoughts believed to be false about the world in the attempt to know the world independently and beyond the experience of it.

It is hard, in my view, to make sense of how the deliberately imaginative escape from the world (which, in fact, translates into the idea that it is possible to escape from ourselves) is supposed to work and how that is supposed to lead the scientist back to the world in a better position to know it. In effect, Vaihinger is advising the scientist to stop testing plausible theories with experiments, and start imagining theories which he does not believe in from the comfort of his armchair, from which knowledge of the world will ensue. We can, however, make sense of why, or in virtue of what, Vaihinger ended up formulating his theory of fictions. It seems to result from the sum of two things: the fact that we can use language analogically (to see this as that, to describe this in comparison with, or on the analogy of, that), by means of which we can even utter senseless propositions, and the theory of language as picture of the world, according to which some propositions are reality.

Wittgenstein's remark on Vaihinger describes the core features of the philosophy of "as if" at the same time as it mentions it as an 
illustration of the points he is making in that context, as discussed in brief above. Hence: Vaihinger takes language as it were at face value and mistakes expressions formed by analogy as reality, where "reality" means a certain set of propositions assumed to fixedly attach to the world. To use an example already mentioned, Vaihinger thinks it is a fiction that "God is the father of men" (Vaihinger 1935: 28), because he is confused about this sentence. He interprets this perfectly significant expression as a claim about "reality", i.e. a claim about biological parenthood and filiation on the analogy of which the expression was probably formed, as if God was a flesh and blood human person who was the first man of mankind. In a word, Vaihinger confuses "as" with "as if". 2

For Vaihinger, expressions supposedly formed by analogy with others must be false, and yet we use them; therefore, he reasons, at least some of them should be useful. Hence, given this train of thought, the usefulness of these fictions becomes, for him, the possibility to use thought beyond the experience of the world. However, as Wittgenstein remarks, that idea has the mere appearance of making sense; and that it is senseless is manifest not because reality "says" so, but because even our grammar rejects it, since our grammar is not alien to experience. So much so that such an appearance "isn't a false appearance either, but rather one that robs us of our orientation" ( $\mathrm{Z}$ \259).

\section{The Golden Bough and Die Philosophie des Als Ob}

It is probably obvious by now what the remark on Vaihinger has to do with the remarks on Frazer. If I am correct, the connection Wittgenstein sees between Vaihinger and Frazer rests on their blind scientific positivism, which leads them to think that analogical uses of language (and symbolic actions) must be fictions - i.e. their tendency to confuse "as" with "as if", and then to imagine that they are able to think beyond what can be logically thought and experienced. Let us see how this connection unfolds and illuminates aspects of language.

\footnotetext{
${ }^{2}$ This is connected with Wittgenstein's well-known discussion of "seeing" and "seeing as", and not "seeing as if", although I cannot make that digression here.
} 
Frazer describes magic as being based on two main principles: the Law of Similarity and the Law of Contact or Contagion. The first is the idea that "like produces like, or that an effect resembles its cause" (Frazer 1994: 26); the second is the idea that things, once in contact with each other, "continue to act on each other at a distance" (26). Frazer is describing analogical processes: similarity and contagion. He then concludes:

In short, magic is a spurious system of natural law as well as a fallacious guide of conduct; it is a false science as well as an abortive art. [...] At the same time it is to be borne in mind that the primitive magician knows magic only on its practical side; he never analyses the mental processes on which his practice is based [...]. In short, to him magic is always an art, never a science; the very idea of science is lacking in his undeveloped mind. (1994: 26-27)

This passage is very revealing. The negative image of the "primitive" man as both ignorant and too dim-witted to mend his ways is not only very unpersuasive, but it is also, most interestingly, an incongruent attempt to circumvent the acknowledged fact that the "primitive magician" does not treat magic as science. Frazer's problem here is this: on the one hand, the "primitive magician" is concerned with practices and "never analyses"; for him, "magic is always an art, never a science". On the other hand, "the magician infers that he can produce any effect he desires" and "infers that whatever he does to a material object will affect equally the person with whom the object was once in contact" (26) - in sum, Frazer now wants to say that his actions are based on a theory, even though the magician is oblivious to "the very idea of science".

Evidently, what had to follow from the attribution of stupidity to the magician should have been the conclusion that the magician is not doing science, as Frazer, in effect, explicitly says. If the magician was doing science, however, Frazer could not have talked so easily of an "undeveloped mind", of Man in his infancy, of magic as fiction; instead, he could only have called the magician ignorant, not dim-witted. Now, if the magician was simply ignorant, he could have been shown to be wrong: his beliefs could have been corrected. However, in reality that idea has no application - and not because the magician is too stupid to be 
corrected. (If he is, he is also too stupid to be able to do science in the first place.)

Therefore, we may very well ask with Wittgenstein how Frazer could have thought that all of those magical practices he described were just "pieces of stupidity" (GB 1993: 119) or "false physics" (129), and how Frazer could have insisted that the "savage" mistook magic for reality: "it is surely remarkable that people don't realize earlier that sooner or later it's going to rain anyhow" (GB 1993: 121); "The same savage, who stabs the picture of his enemy apparently in order to kill him, really builds his hut out of wood and carves his arrow skillfully and not in effigy" (125).

For Wittgenstein, the idea of an error has application only where there is a theory (119) or an opinion (123), i.e. "when magic is interpreted scientifically" (125). However, while "the characteristic feature of ritualistic action is not at all a view, an opinion, whether true or false, [...] an opinion - a belief - can itself be ritualistic or part of a rite" (129). In this latter instance, Wittgenstein is talking about beliefs such as e.g. the specific date at which Christians celebrate the birth of Jesus, and this kind of belief is as much an integral part of the celebration as it is of its explanation. By saying this we have given an explanation in the minimal sense, the same sense in which Wittgenstein writes that the confession of sins "admits of being "explained and not explained" (123); and: "Here one can only describe and say: this is what human life is like" (121). Now, one may wish to argue that Wittgenstein is manifesting some form of obscurantism here, but I believe Hacker has already dissolved that objection (2001: 74-97). Wittgenstein is simply saying that the explanation of a rite is rendered intelligible in a description of that practice, and specific elements within the practice can be explained with reference to it; nothing else is required.

However, as Hacker has seen clearly, alien practices demand from us a particular exercise so that they can be, in a special sense, understood. This is a very important point. Wittgenstein is not simply taking the practices described in The Golden Bough as curious oddities one can find out about in this world. In trying to understand them he is relating them to practices he is familiar with. 
As Hacker writes, he is "associating the baffling rite with a comparable impulse in $u s "$ (2001: 75); and: "His concern is not with 'How did these sinister practices originate?' nor with 'What do they mean?' but with 'What do they mean to us??' (76). In short, and most importantly for my purposes, the same kind of analogical process by means of which a magical rite is constituted and is intelligible to the participants ("this as that", and not necessarily the mistake of "this as if that") is precisely the kind of analogical reasoning Wittgenstein uses to understand them: these alien practices are like the ones I am familiar with. The idea is not new, for the intelligibility by familiarity is how, in the Poetics, Aristotle explains the way we understand characters: "houtos ekeinos" (1448b17), "this is the other", i.e. "this character before me is like this other man I know". This means that, in order to understand the "savage", the outside viewer should not treat his practices as irrational oddities, as Frazer does, much less entertain the makebelieve fantasy of "going primitive" in order to "really know" what it is like (as if one could become a "savage" by taking one's clothes off), but rather the much more sensible hermeneutic stance of comparing what he does with what we know and do. Hacker writes:

Wittgenstein invokes our primal inclinations, symbolizing propensities and responses to elemental experience, not as a substitute for articulating the constituent beliefs of a practice (where they are known), but as a condition for their intelligibility. [...] The 'appeal to a tendency in ourselves' is a condition of our finding the symbolism of ritual, the 'extremely developed gesture-language' intelligible. And it is equally a condition of our being able to grasp, to whatever extent we can, the beliefs that are partly constitutive of a rite as reasons for the ritual action.

If 'the common behaviour of mankind is the system of reference by means of which we interpret an unknown language' (PI \$206), then the common wonder of mankind [...] and the forms of impulse, symbolic and expressive, to which it gives rise in us is the point of reference for rendering intelligible the meaning of magical rites of primitive societies. For a culture that lacked a sense of wonder $[\ldots]$ would find the symbolic rites and beliefs of magic wholly unintelligible, and would perhaps think to account for them, as Frazer did, simply in terms of erroneous proto-scientific beliefs. (Hacker 2001: 92-93) 
The only words I would not use in this exceptional passage are the ones bearing the resonance of an essential "inner" space, such as "primal", "impulse", or "expressive" - not because I think Hacker is using these words in the wrong way, but because I would like to avoid giving the slightest weight to the idea that Wittgenstein's position on rites is e.g. expressivist. Wittgenstein is much less focused, if not at all, in giving an account or a theory of religion than he is focused on illuminating aspects of language and interpretation; his remarks are about coping with and, in a special sense, understanding unfamiliar humans. And he is showing in practice how we can understand alien people, by comparing the way they make comparisons, just like us - because they are fundamentally like us. We share the same grammar and particular differences between them and us have simply to do with "[t] he surroundings of a way of acting" (GB 1993: 147). Wittgenstein writes:

It was not a trivial reason, for really there can have been no reason, that prompted certain races of mankind to venerate the oak tree, but only the fact that they and the oak were united in a community of life, and thus that they rose together not by choice, but rather like the flea and the dog. (If fleas developed a rite, it would be based on the dog.) (139)

The initial and as it were given familiar environment we breathe in, then, is our condition of the intelligibility of the world; from there, we are able to understand and create unfamiliar ways of using language, on the analogy of what we already say and do.

To conclude, let us look at MS 110: 255-256, this time with the exclusion of the remark signalled " $\mathrm{S}$ " and the one with a question mark in the left margin. We are left with this:

Man kann nur scheinbar „über jede mögliche Erfahrung hinausgehen"; ja, dieses Wort hat auch nur scheinbar Sinn, weil es nach Analogie sinnvoller Ausdrücke gebildet ist. [Z \$260]

Wenn es einem Menschen freigestellt wäre sich in einen Baum eines Waldes gebären zu lassen: so gäbe es Solche, die sich den schönsten oder höchsten Baum aussuchen würden, solche die sich den kleinsten wählten und solche die sich einen Durchschnitts- oder minderen Durchschnittsbaum wählen würden, und zwar meine ich nicht aus Philiströsität, sondern aus eben dem Grund, oder der Art von Grund, warum sich der Andre den höchsten gewählt hat. Daß das Gefühl 
welches wir für unser Leben haben mit dem eines solchen Wesens, das sich seinen Standpunkt in der Welt wählen konnte, vergleichbar ist, liegt, glaube ich, dem Mythus - oder dem Glauben - zugrunde, wir hätten uns unsern Körper vor der Geburt gewählt. [GB 1993: 136]

Die „Philosophie des Als Ob” beruht ganz auf diese Verwechslung zwischen Gleichnis und Wirklichkeit. [Z \261]

In den alten Riten haben wir den Gebrauch einer äußerst ausgebildeten Gebärdensprache.

Und wenn ich in Frazer lese so möchte ich auf Schritt \& Tritt sagen: Alle diese Prozesse diese Wandlungen der Bedeutung haben wir noch in unserer Wortsprache vor uns. Wenn das was sich in der letzten Garbe verbirgt der Kornwolf genannt wird, aber auch diese Garbe selbst, und auch der Mann der sie bindet, so erkennen wir hierin einen uns wohlbekannten sprachlichen Vorgang. [GB 1993: 134]

These remarks are not written in a strict linear sequence, except the last two ( $Z$ \$261 and GB 1993: 134), since, as explained in section 1, Wittgenstein had them typed in sequence in TS 211: 281. Therefore, and given my earlier discussion in sections 2 and 3, Wittgenstein is not saying here that the expression of beliefs such as the ones mentioned in GB 1993: 136 is necessarily a case of "transcending any possible experience", nor is he saying that such beliefs rest on the confusion he identifies in Vaihinger's "as if". What he was originally thinking was that the analogical formation of expressions that constitute the description of magical rites and religious beliefs could be the case (as he says in Z \$259) of a picture that "robs us of our orientation", if the analogy was understood not as a simile, but mistaken for "reality". This, Wittgenstein remarks, is the confusion in which the core of Vaihinger's "as if" is based; and this is also what Frazer seems to have known but refused to see, for if the "savage" was not doing the same kind of things we did - i.e. if the "savage" was indeed like Frazer describes him (an undeveloped mind, unaware of the actual world) interpreting alien rites as based on theories would have been akin to fantasize about the theories cats might have about the world. To do so, like Frazer does, is just another case of trying to think the unimaginable; and it is only a case of trying to, for Frazer naturally ends up interpreting magic and religion as much in terms of what 
he knows as the next person, although only half-aware of doing so, just like Vaihinger.

\section{References}

Aristotle, 1995. The Complete Works of Aristotle, Volume Two, ed. J. Barnes. Princeton, NJ: Princeton University Press.

Biesenbach, H., 2011. Anspielungen und Zitate im Werk Ludwig Wittgensteins. Publications from the Wittgenstein Archives at the University of Bergen, 22. Bergen: The Wittgenstein Archives at the University of Bergen.

Bouriau, C., 2009. "Vaihinger and Poincaré: An Original Pragmatism?” In: M. Heidelberger and G. Schiemann, eds. 2009. The Significance of the Hypothetical in the Natural Sciences. Berlin and New York: Walter de Gruyter, pp. 221-249.

Cioffi, F., 1998. Wittgenstein on Frend and Frazer. New York: Cambridge University Press.

Clack, B. R., 1998. Wittgenstein, Frazer and Religion. Basingstoke and New York: Palgrave.

Drury, M. O'C., 1984. “Conversations with Wittgenstein”. In: R. Rhees, ed. 1984. Recollections of Wittgenstein. Oxford: Oxford University Press, pp. 97-171.

Fine, A., 1993. "Fictionalism". Midwest Studies in Philosophy, XVIII, pp. 1-18.

Frazer, J. G., 1994. The Golden Bough - A Study in Magic and Religion. A new abridgement from the second and third editions, ed. R. Fraser. New York: Oxford University Press.

Hacker, P. M. S., 2001. Wittgenstein: Connections and Controversies. Oxford: Clarendon Press.

Lugg, A., 2010. "Wittgenstein on Reddish Green: Logic and Experience". In: A. Marques and N. Venturinha, eds. 2010. Wittgenstein on Forms of Life and the Nature of Experience. Bern: Peter Lang, pp. 155-181.

Mead, G. R. S., 1913. Quests Old and New. London: G. Bell \& Sons. Available at:

$<$ https://archive.org/stream/cu31924022917714\#page/n7/mode/2u p> [Accessed 30 August 2014]

Orzechowski, A., and Pichler, A., 1995. "A Critical Note on the Editions of Wittgenstein's Remarks on Frazer's Golden Bough". Wittgenstein Studies 2/95 [online]. Available at: <http://sammelpunkt.philo.at:8080/466/1/21-2-95.TXT> [Accessed 30 August 2014].

Rothhaupt, J. G. F., 1995. "Ludwig Wittgenstein und Paul Ernst 'Mißverstehen der Sprachlogik"'. Wittgenstein Studies 2/95 [online]. 
Available at: <http://sammelpunkt.philo.at:8080/467/1/23-2-

95.TXT $>$ [Accessed 30 August 2014]

Stampfl, B., 1998. "Hans Vaihinger's Ghostly Presence in Contemporary

Literary Studies". Criticism, 40, no. 3, pp. 437-454.

Szasz, T. S., 1974. The Myth of Mental Illness. New York: Harper \& Row.

Vaihinger, H., 1935. The Philosophy of 'As If': A System of the Theoretical, Practical and Religious Fictions of Mankind, $2^{\text {nd }}$ ed., trans. C. K. Ogden. London:

Routledge and Kegan Paul.

von Wright, G. H., 1982. Wittgenstein. Oxford: Basil Blackwell.

Wittgenstein, L., 1958. Philosophical Investigations / Philosophische Untersuchungen,

$2^{\text {nd }}$ ed., ed. G. E. M. Anscombe and R. Rhees, trans. G. E. M.

Anscombe. Oxford: Basil Blackwell. [PI]

Wittgenstein, L., 1967. "Bemerkungen über Frazers Golden Bough", ed. R.

Rhees. Synthese, 17, pp. 233-253. [GB 1967]

Wittgenstein, L., 1975. Philosophical Remarks, ed. R. Rhees, trans. R.

Hargreaves and R. White. Oxford: Blackwell. [PR]

Wittgenstein, L., 1977. Remarks on Colour, ed. G. E. M. Anscombe, trans. L.

L. McAlister and M. Schättle. Oxford: Blackwell. [ROC]

Wittgenstein, L., 1980. Remarks on the Philosophy of Psychology, volume I, ed. G. E.

M. Anscombe and G. H. von Wright, trans. G. E. M. Anscombe.

Oxford: Blackwell. [RPP I]

Wittgenstein, L., 1980. Remarks on the Philosophy of Psychology, volume II, ed. G.

H. von Wright and H. Nyman, trans. C. G. Luckhardt and M. A. E.

Aue. Oxford: Blackwell. [RPP II]

Wittgenstein, L., 1981. Zettel, ed. G. E. M. Anscombe and G. H. von Wright, trans. G. E. M. Anscombe. Oxford: Blackwell. [Z]

Wittgenstein, L., 1993. "Bemerkungen über Frazers Golden Bough / Remarks on Frazer's Golden Bough". In: J. C. Klagge and A. Nordmann, eds. 1993. Philosophical Occasions 1912-1951. Indianapolis and Cambridge,

USA: Hackett, pp. 115-155. [GB 1993]

Wittgenstein, L., 1993. Philosophical Occasions 1912-1951, eds. J. C. Klagge and

A. Nordmann. Indianapolis and Cambridge, USA: Hackett. [PO]

Wittgenstein, L., 2000. Wittgenstein's Nachlass: The Bergen Electronic Edition.

Oxford: Oxford University Press. [BEE] 


\section{Biographical note}

Carlos A. Pereira is a researcher in philosophy at the NOVA Institute of Philosophy, Lisbon, and a doctoral candidate in Literary Theory from the University of Lisbon, with a thesis on the concept of fiction. His research focuses on the philosophy of language, literary theory and criticism, Ludwig Wittgenstein and Donald Davidson. He has written on Wittgenstein ("Sobre o Tractatus e as Investigações", in Venturinha, Nuno (ed.), Linguagem e Valor, Lisbon: Instituto de Filosofia da Linguagem, 2011, pp. 65-73) and on the concepts of fetishism and fiction. 